アトピーのレーザー治療10年。その問題点。

福井安彦

$$
\text { クリニック・フクイ }
$$

Results from 10 Years of Laser Treatment for Atopic Dermatitis

\title{
Yasuhiko Fukui
}

Clinic Fukui

I opened a clinic 10 years ago to treat atopic dermatitis with laser. However, nearly all of the 2,650 cases treated had developed steroid dermatitis.

1) Non-steroidal treatment for atopic dermatitis

The following forms a non-steroidal treatment for atopic dermatitis.

a) Behavioural medicine

Getting up early and going to bed early, and a balanced diet are put into practice to stabilize the autonomic nerves.

b) Oolong tea bath

Oolong tea bath is used to avoid the use of steroids on the entire body. It has an effect to reduce redness and itchness that accompany atopic dermatitis.

c) Hot shower treatment

The use of hot shower sedates itchness and reduces scabs.

d) Carbon oxide gas laser

Carbon oxide gas laser has anti-phlogistic and anti-inflammatory effects on atopic and steroid dermatitis.

2) Differences between atopic dermatitis and steroid dermatitis (questions towards so-called "adult" atopic. dermatitis).

3) Suggestion to the Ministry of Health to establish a council to research the side effects of steroids and save the patients with steroid dermatitis.

10年前からアトピーをレーザーで治療 する目的で開業したが、ステロイド皮膚 症を終日治療する結果となった。

(2650例)
1）ステロイドを使わないアトピー治 療。 次の 4 つの治療により、ステロイドに よらないアトピー治療が完成された。 


\section{(1)行動医学。}

「早寝・早起き」「偏食のない食 事」へと問題点の改善により自律神 経の安定をもたらす。

(2)ウーロン茶沐浴。

ステロイドの全身的適用を完全に 回避する目的で使用、アトピーの発 疹並痒みを少くする効果がある。

（1日3〜4回）

(3)ホット・シャワー療法。

入浴時、ホット・シャワーを使用 することにより、痒みが消えかさぶ たも落ち易くなる。

(4)炭酸ガスレーザー。

アトピー並にステロイド皮膚症に 止痒、消炎効果あり。

以上の 4 つの療法を立体的に行うこと で、重度のアトピーもステロイド皮膚症も 治療出来る様になった。

2 ) アトピー性皮膚炎とステロイド皮覤症 の診断。

成人型アトピー性皮膚炎は殆どがステロ イド皮痛症の症状を示しているのに、その 診断を故意に混同している傾向がある。

3 ）厚生省に「ステロイド副作用に関する 調查会」設置を提案する。

ステロイド皮䖉症の患者救済のために是 非必要である。 